\title{
Polygenic Risk Score associated with specific symptom dimensions in first-episode psychosis
}

Authors: Sarojini M. Sengupta $\mathrm{PhD}^{\mathrm{a}, \mathrm{b}}$, Kathleen McDonald $\mathrm{MSc}^{\mathrm{a}, \mathrm{b}}$, Ferid Fathalli $\mathrm{MD}^{\mathrm{a}, \mathrm{b}}$, Anita Yim ${ }^{c}$, Martin Lepage $\mathrm{PhD}^{\mathrm{a}, \mathrm{b}, \mathrm{d}}$, Srividya Iyer $\mathrm{PhD}^{\mathrm{a}, \mathrm{b}}$, Ashok Malla MD ${ }^{\mathrm{a}, \mathrm{b}}$, Ridha Joober MD, PhD a,b,d,e

\section{Author affiliations:}

a. Douglas Mental Health University Institute, 6875 LaSalle Blvd, Verdun, Quebec, Canada, H4H 1R3.

b. Department of Psychiatry, McGill University, Ludmer Research \& Training Building, 1033 Pine Ave. West, Montreal, Quebec, Canada H3A 1A1.

c. Department of Medicine, Université de Sherbrooke, Local E5-1283 Sherbrooke, Québec, Canada J1K 2R1.

d. Integrated Program in Neuroscience, McGill University, Room 141, Montreal Neurological Institute, 3801 University Street, Montreal, Quebec, Canada H3A 2 B4.

e. Department of Human Genetics, McGill University, Room N5-13, Stewart Biology Building, 1205 Dr. Penfield Ave., Montreal, Quebec, Canada H3A 1B1.

Corresponding Author: Sarojini M. Sengupta, Douglas Mental Health University Institute, 6875 LaSalle Blvd, Verdun, Quebec, Canada, H4H 1R3.

Tel: 1-514-761-6131 X 3429

Fax: 1-514-888-4064

Email: sarojini.sengupta@douglas.mcgill.ca 


\section{Acknowledgments:}

This work was supported in part by grants from the Fonds de recherche du Québec-Santé and the Canadian Institutes of Health Research to RJ, AM, and ML. SMS is a recipient of the 2008 NARSAD Young Investigator, 2009 Dr. Mortimer D. Sackler Developmental Psychology Investigator Awards, and AACAP Outstanding Mentor Award. We thank members of PEPPMontreal for technical and clinical assistance, and Dr Katherine J Aitchison for helpful comments on the manuscript. We express our sincere gratitude to all individuals who participated in this study. 


\begin{abstract}
Recent Genome-Wide Association Studies (GWAS) have provided evidence for the involvement of a number of genetic variants in schizophrenia (SCZ). The objective of the current study was to examine the association between these variants and symptom dimensions, evaluated prospectively over a period of 24 months, in a clinically well-characterized sample of individuals $(n=241)$ with first-episode psychosis (FEP). The genetic variants were analyzed collectively as captured through a Polygenic Risk Score (PRS), calculated for each individual. At each evaluation time point (baseline, 1, 2, 6 and 24 months), correlation analysis was conducted with PRS and symptom dimension scores assessed by the Positive and Negative Syndrome Scale (PANSS). We also examined the association of PRS with global symptom rating, depression, anxiety, social and occupational functioning as measured by widely used and well validated scales. At baseline, significant positive correlation was observed between PRS and the general psychopathology dimension of the PANSS but no associations were observed with the positive or negative symptom dimensions. Anxiety, assessed using the Hamilton Anxiety Rating Scale, was also significantly correlated with the PRS. No significant correlation was observed with other symptom dimensions or with the PANSS score at the later evaluations. These results provide novel evidence of an association between general psychopathology and PRS in young people with first episode psychosis. They also demonstrate that it is important to note the dynamic changes of symptoms over time when trying to refine the relationship between genetic factors and phenotypes.
\end{abstract}

Keywords: Schizophrenia, First-episode psychosis, Polygenic Risk Score, General psychopathology, PANSS, Anxiety 


\section{Introduction}

Schizophrenia (SCZ) spectrum psychoses are often regarded as the most serious of all mental disorders. The primary symptoms are positive (delusions, hallucinations, disorganization of thought and behavior), with to a varying degree, negative (poverty of thought and affect, apathy and social withdrawal), depressive, manic and anxiety symptoms in the acute phase; and residual symptoms and social disability in the longer term. With onset typically occurring during adolescence or early adulthood, psychotic disorders have serious long-term implications including reduced life expectancy (Chang et al., 2011), disruption of social and emotional development, education underachievement, unemployment (Switaj et al., 2012), and suicide (Hor and Taylor, 2010).

Schizophrenia spectrum disorders have a strong genetic component, and it is now wellelucidated that a large number of independent loci contribute to their etiology, each adding only a small risk. Both common and rare risk variants have been implicated. It has been estimated that a half to one-third of the genetic risk is indexed by common alleles that can be assayed in GenomeWide Association Studies (GWAS) (International Schizophrenia Consortium et al., 2009; Ripke et al., 2013). Recently, the Schizophrenia Working Group of the Psychiatric Genomics Consortium reported results of the most recent GWAS conducted with a sample size $>150,000(36,989$ cases and 113,075 controls) (Schizophrenia Working Group of the Psychiatric Genomics Consortium, 2014). 108 independent genetic loci were shown to be associated with SCZ, passing criteria for genome-wide significance $\left(\mathrm{P} \leq 5 \times 10^{-8}\right)$. A recent advancement in psychiatric genetics has been the use of a Polygenic Risk Score (PRS) in association analyses (International Schizophrenia Consortium et al., 2009). A PRS is essentially derived by aggregating genetic risk variants identified from GWAS into one score. The major advantage of this approach is that the power of 
a large GWAS can be robustly utilized for a smaller sample, since the statistical power of a PRS is exponentially better compared to that of a single SNP (Dima and Breen, 2015).

Several recent studies have examined the association between SCZ PRS score with symptoms of the disorder. In one of the first studies of this kind, PRS score was shown to be significantly different when comparing cases versus controls (Derks et al., 2012). However, within the affected group, no association was observed between PRS and any of the 5 symptom dimensions of psychosis analyzed (depression, disorganization, mania, positive and negative symptoms). A second study reported a lack of association between SCZ PRS and "psychotic experiences" in a large non-clinical community sample of adolescents between 12 to 18 years of age (Sieradzka et al., 2014). Here the instrument used was the Specific Psychotic Experiences Questionnaire (SPEQ) which includes self-reported paranoia, hallucinations, cognitive disorganization, grandiosity, anhedonia, and parent-rated negative symptoms. This group also used the Psychotic-Like Symptoms Questionnaire (PLIKS-Q), but observed no association with SCZ PRS. In yet another study, conducted with the large non-clinical ALSPAC cohort, no association was observed between SCZ PRS and psychotic experiences (Zammit et al., 2014). Psychotic experiences were assessed, at 12 years of age, as a single categorical construct (i.e. any one of a number of different positive experiences).

In the studies described above, SCZ PRS was derived from earlier GWAS that identified 13 risk loci (Ripke et al., 2013). More recent studies have derived a SCZ polygenic risk score from the 108 loci implicated in the most recent GWAS (Schizophrenia Working Group of the Psychiatric Genomics Consortium, 2014). In a study conducted with adolescents from the ALSPAC cohort, measures of negative symptoms, depressive and anxiety disorders were added to the PLIKS-Q described above (Jones et al., 2016). As before, no association was observed with 
psychotic experiences. However, significant association was observed between SCZ PRS and negative symptoms as well as anxiety disorders. In another recent study, no association was observed with symptom severity and overall functioning as measured by the Global Assessment of Functioning (GAF) scale, nor with antipsychotic dosage (Hettige et al., 2016).

While the results of these studies are interesting, the major disadvantage is that they were most likely conducted in patients at different stages of the illness and treatment, which may obscure any relationship between symptoms and PRS. A recent study, conducted with a sample of firstepisode psychosis (FEP) patients, concluded that PRS was a reliable predictor of case-control status (Vassos et al., 2016). However, no analysis was presented on the association of PRS with symptom dimensions of SCZ. The objective of the current study was to use a clinically wellcharacterized sample of individuals with FEP, who are engaged in a structured treatment program: (1) to refine the association between the SCZ PRS and symptom dimensions of psychotic disorder, and, (2) to examine the association of SCZ PRS with symptom dimensions over the course of the two-year treatment period. The advantages of such a sample are that the clinical manifestations of illness are not confounded by long-term exposure to medication, chronicity, and social deprivation.

\section{Materials and Methods}

\subsection{Subjects}

Individuals were recruited from among FEP patients treated at the Prevention and Early Intervention Program for Psychoses in Montreal (PEPP- Montréal) between 2003-2013. This program is a specialized, publicly-funded, early-intervention service that provides intensive medical and psychosocial management over a 24 month period (Iyer et al., 2015). PEPP- Montréal is an integrated clinical and research program that constitutes the only service for FEP patients 
within a large catchment area (population of 400 000) in southwest Montréal, without alternative competing programs in its vicinity. Inclusion criteria are as follows: (1) age between 14 and 35 years; and (2) diagnoses of affective (Bipolar Disorder and Major Depressive Disorder with psychotic features) or non-affective (Schizophrenia, Schizoaffective Disorder, Schizophreniform disorder, Delusional Disorder and Psychosis Not Otherwise Specified) FEP. The clinical diagnosis is made using the Structured Clinical Interview for DSM-IV-TR (Diagnostic and Statistical Manuel for Mental Disorders, fourth edition, text revised). All diagnoses are confirmed at a consensus meeting attended by a senior research psychiatrist (RJ or AM). Only individuals with less than 30 cumulative days of treatment with antipsychotic medication are included in the program.

Of the 660 clients meeting criteria for admission to PEPP-Montreal, 573 consented to participate in the research arm of the program. These individuals were subsequently approached to participate in the genetic study, and written informed consent was obtained from those interested $(n=241)$. This study was approved by the Ethics Review Board at the DMHUI and McGill University.

As part of the program, patients are stabilized on second-generation anti-psychotic medication following a defined protocol. The program uses standardized structured evaluations to monitor symptoms, and implement treatment plans tailored to the needs of the patient. Evaluations are conducted at regular intervals (baseline and months 1,2,3, 6, 12, 18 and 24) by highly trained research staff. Inter-rater reliability sessions are regularly held and any observed drift in ratings is corrected.

\subsection{Instruments and assessment}


Symptoms were assessed using the Positive and Negative Syndrome Scale (PANSS) (Kay et al., 1988; Kay et al., 1989). This scale is a standardized, validated instrument devised for the assessment of symptoms. It consists of 30 items, each rated on a 7-point scale of severity. Of the 30 items, an equal number of items are summed in the overall positive symptom score ( 7 items) and negative symptom score ( 7 items). The remaining 16 items constitute a measure of "general psychopathology". The inclusion of a scale to measure general psychopathology has been noted to be one of the key advantages over the other instruments widely used to assess symptoms: Scale for the Assessment of Positive Symptoms (SAPS) and Scale for the Assessment of Negative Symptoms (SANS) (Kay et al., 1988). The general psychopathology index was intended to serve as a measure of overall severity of illness, independent of positive and negative symptoms. Symptomatic state/ outcome was assessed using the Global Assessment of Functioning (GAF) scale. Since comorbid anxiety disorders and depression are common with psychotic disorders, assessment using the Hamilton Anxiety Rating Scale (HARS) (Hamillton, 1959) and Calgary Depression Scale for Schizophrenia (CDSS) (Addington et al., 1990) were also conducted at each evaluation. Psychosocial functioning was assessed at baseline and 24-month follow-up using the Social and Occupational Functioning Assessment Scale (SOFAS) (Goldman et al., 1992). These scales are extensively used in treatment outcome studies.

\subsection{Genetics}

DNA was extracted from blood or saliva samples collected from each participant. Of the 128 initial sites showing a significant association in the SCZ GWAS, several overlapping regions were implicated (Schizophrenia Working Group of the Psychiatric Genomics Consortium, 2014). In order to define loci conservatively so as to include only physically independent regions of the 
genome, associated regions that were not separated by at least $250 \mathrm{~kb}$ were merged to obtain 108 loci in the GWAS. From each of these merged regions, only one single nucleotide polymorphism (SNP) was selected for genotyping. A total of 10 chromosomal regions lacking a unique SNP ID (chr1_8424984_D; $\quad$ chr2_146436222_I; chr2_149429178_D; chr2_200825237_I; chr5_140143664_I; chr6_84280274_D; chr7_2025096_I; chr7_24747494_D; chr11_46350213_D; chr11_46350213_D) were not included in the panel for genotyping. A total of 98 SNPs were therefore selected for genotyping using Sequenom iPlex Gold Technology at the McGill Innovation Center, Montreal (Ehrich et al., 2005) - SNP rs1 15329265 was genotyped under the alias rs 1233578 as given in dbSNP. Of these:

1) 6 failed at primer design due to repeated region (rs35518360, rs12704290, rs140505938, rs7819570, rs12845396, rs56873913);

2) 1 failed at primer design due to neighbor SNPs (rs5937157);

3) 4 failed at the stage of genotyping (rs1702294, rs11693094, rs6002655, rs11139497);

4) 3 were excluded from the final analysis since the genotyping call rate was less than $90 \%$ (rs8042374, rs75059851, rs679087);

A total of 84 SNPs were successfully genotyped with a call rate greater than $90 \%$. Every plate included duplicates of two reference samples used to estimate genotyping error. Genotypes for these samples were read with $100 \%$ accuracy on each of the plates.

For each SNP, the "risk allele" was unambiguously assigned based on the PGC GWAS (Schizophrenia Working Group of the Psychiatric Genomics Consortium, 2014). Each individual was assigned a score of 0,1 or 2 depending on the presence of 0,1 , or 2 copies of the risk allele respectively. For each SNP, the score was multiplied by the Odds Ratio obtained in the GWAS. The scores for each SNP for each individual were summed to give the Polygenic Risk Score (PRS) 
for each individual. Only those DNA samples having a call rate greater than $90 \%(\mathrm{n}=215)$ were included in the final PRS analysis in order to apply strict quality control criteria.

\subsection{Statistical analysis}

Correlation analysis was conducted (in SPSS) between PRS and each of the symptom dimension scores at each time point. Since 5 clinical domains were tested for association with PRS (PANSS, GAF, HARS, CDSS, and SOFAS), correction for multiple testing was applied, and the threshold for significance was set at $\mathrm{P}<0.01(0.05 / 5)$. A highly significant correlation was observed between the total and dimensional scores of the PANSS at each time point (Supplementary Table; S1). Correction was not applied for each of the SNPs that together form the composite polygenic risk score since these SNPs were the most validated genetic factors in the SCZ GWAS, with the objective of balancing Type I and Type II error.

\section{Results}

Demographic and clinical characteristics are presented for subjects participating in the genetic study (Table 1). Relative to those who did not participate in the genetic study, the group of individuals who did participate were younger and less likely to have completed high school, had lower IQ, lower age of onset of psychotic symptoms, and a significantly higher PANSS positive symptom sub-scale score. A significant correlation was observed between SCZ PRS and baseline measures: (1) general psychopathology assessed by the PANSS, (2) anxiety assessed by the HARS (Table 2a). Higher PRS score was associated with higher scores on the general psychopathology subscale, as well as greater anxiety symptoms. By month1 evaluation and lasting till the 24 month evaluation, a lack of association was noted between PRS and any of the symptom measures. It may be noted that after the first month of treatment, there is a significant decrease in 
symptoms, particularly positive and general psychopathology symptoms (Table 2b). No association was observed with CDSS, SOFAS and GAF scores at any of the time points (Table 2a).

This analysis was conducted in a sample with $76.4 \%$ Caucasian ethnicity. However the SCZ GWAS data used to derive the Odds Ratio used in the PRS analysis are from Europeanderived and (a small proportion of) Asian samples. In order to ensure that the results are not confounded by population stratification, the analysis was repeated in a subset of the sample including only those with Caucasian ethnicity. Here again, the demographic characteristics were significantly different from those Caucasian subjects who did not give consent to participate (younger, with a lower age of onset), though the two groups did not differ with respect to their clinical dimensions (Table 3). Given that the smaller Caucasian sample likely has lower statistical power, a less stringent threshold for significance $(\mathrm{P}<0.05)$ was applied to this post hoc analysis. Once again, significant correlation was observed between SCZ PRS and baseline measures of: (1) general psychopathology and negative symptoms assessed by the PANSS, (2) anxiety assessed by the HARS (Table 4).

\section{Discussion}

Here we report an association between general psychopathology and SCZ PRS, noted for the first time in young people with first episode psychosis. The most important contribution of this study is the detailed and systematic assessment of symptoms conducted as treatment progresses over a two-year period. By following the course of symptom progression, it is clear that the association with psychopathology is most significant at the acute phase of the illness, when patients first enter the treatment program and while their symptoms are still actively expressed. As the 
acute symptoms remit, association is no longer observed. The second interesting result noted is the association between SCZ PRS and anxiety symptoms. These results show an important internal consistency since anxiety is one of the items on the general psychopathology scale (PANSS G2anxiety).

It is also interesting that even at the acute phase of the illness, no association is observed with positive symptoms. Several previous studies have examined SCZ PRS with positive symptoms or psychotic experiences in different populations (Derks et al., 2012; Jones et al., 2016; Sieradzka et al., 2014). However, none of these studies reported an association. In the most recent study, examining various symptom dimensions in the ALSPAC cohort, an association was observed with negative symptoms and anxiety disorder but not with psychotic experiences and depressive disorder (Jones et al., 2016), similar to our observation in youth with FEP. These results suggest that the genetic variations identified in the SCZ PRS increase the risk for psychotic disorders through a general susceptibility to mental illness. This susceptibility may find expression in manifestation of different symptoms (positive, negative, mood, etc.). Such a vulnerability model is compatible with the observation that a spectrum of severe mental illnesses share an important fraction of their genetic vulnerability. It is also possible that the lack of association with positive symptoms may be an artifact arising from the sampling methods used in the GWAS. By virtue of it being a large conglomerate of samples, it necessarily includes patients at vastly different stages of the disorder and with a diverse spectrum of symptoms. It is therefore reasonable that an association is observed with overall psychopathology related to psychosis and not with any specific symptoms.

The major limitation of our study is the relatively small sample size. Despite being one of the largest longitudinal samples of individuals with first episode psychosis, it may not be 
adequately powered to identify small effects of cumulative genetic risk. However, it is important to note that using the PRS approach helps capitalize on the power of large GWAS (which have minimal phenotyping) to be used in smaller genetic studies having exquisite phenotyping. The second major limitation of the study is that some of the demographic/clinical features of clients who respond to the invitation to participate in the genetic study are different from those who do not (Table 1). However, it may be noted that all individuals are gauged on their ability to provide informed consent before being approached, and not on the basis of any genetic selection criteria. The clinical/demographic differences in the two groups should therefore not have a significant impact on a genetic association study. However it is underscored that this may present a limitation to the generalizability of findings to the entire FEP sample.

It is also noted that many polygenic studies use larger sets of SNPs with decreasingly lower significance, and find that the variance explained by PRS and the significance improves compared to PRS using only 108 SNPs. However this analysis requires genome-wide SNP data, which is not available for this sample. This may represent an important limitation of the study and may explain why associations with other symptom dimensions were not observed. Nonetheless, it is remarkable that all the results obtained in the current study are completely consistent with previous studies. In addition to earlier reports on lack of association with positive symptoms, a recent study reported a lack of association between SCZ PRS and symptom severity/ overall functioning, as assessed by the GAF (Hettige et al., 2016). This result is consistent with our findings of a lack of association with symptom severity evaluated by GAF. Perhaps combining the two important strengths of large GWAS with systematic, detailed phenotyping presents an important step forward in the field. Despite these interesting results, more molecular work needs to be done to understand how specific pathways are related to the onset of psychosis. 


\section{Disclosures}

Dr. Sarojini M. Sengupta has no competing interests to disclose. Dr. Martin Lepage reports having received financial assistance/compensation for research and educational events from Janssen-Ortho, Eli Lilly, Roche, and Otsuka/Lundbeck Alliance. Dr. Ridha Joober is on the advisory boards and speakers' bureaus of Pfizer, Janssen Ortho, BMS, Sunovion, Otsuka and Lundbeck. He has received grant funding from them and from AstraZeneca. He has received honoraria from Janssen Canada, Shire, Lundbeck, Otsuka and from Pfizer Canada for CME presentations and royalties for Henry Stewart talks.

\section{Reference List}

Addington, D., Addington, J., Schissel, B., 1990. A depression rating scale for schizophrenics. Schizophr. Res. 3 (4) 247-251.

Chang, C.K., Hayes, R.D., Perera, G., Broadbent, M.T., Fernandes, A.C., Lee, W.E., Hotopf, M., Stewart, R., 2011. Life expectancy at birth for people with serious mental illness and other major disorders from a secondary mental health care case register in London. PLoS. One. 6 (5) e19590.

Derks, E.M., Vorstman, J.A., Ripke, S., Kahn, R.S., Ophoff, R.A., 2012. Investigation of the genetic association between quantitative measures of psychosis and schizophrenia: a polygenic risk score analysis. PLoS. One. 7 (6) e37852.

Dima, D., Breen, G., 2015. Polygenic risk scores in imaging genetics: Usefulness and applications. J. Psychopharmacol. 29 (8) 867-871.

Ehrich, M., Bocker, S., van den Boom, D., 2005. Multiplexed discovery of sequence polymorphisms using base-specific cleavage and MALDI-TOF MS. Nucleic Acids Res. 33 (4) e38.

Goldman, H.H., Skodol, A.E., Lave, T.R., 1992. Revising axis V for DSM-IV: a review of measures of social functioning. Am. J. Psychiatry. 149 (9) 1148-1156.

Hamillton, M., 1959. The assessment of anxiety states by rating. Br. J. Med. Psychol. 32 (1) 5055 .

Hettige, N.C., Cole, C.B., Khalid, S., De Luca, V., 2016. Polygenic risk score prediction of antipsychotic dosage in schizophrenia. Schizophr. Res. 170 (2-3) 265-270. 
Hor, K., Taylor, M., 2010. Suicide and schizophrenia: a systematic review of rates and risk factors. J. Psychopharmacol. 24 (4 Suppl) 81-90.

International Schizophrenia Consortium, Purcell, S.M., Wray, N.R., Stone, J.L., Visscher, P.M., O'Donovan, M.C., Sullivan, P.F., Sklar, P., 2009. Common polygenic variation contributes to risk of schizophrenia and bipolar disorder. Nature. 460 (7256) 748-752.

Iyer, S., Jordan, G., MacDonald, K., Joober, R., Malla, A., 2015. Early intervention for psychosis: a Canadian perspective. J. Nerv. Ment. Dis. 203 (5) 356-364.

Jones, H.J., Stergiakouli, E., Tansey, K.E., Hubbard, L., Heron, J., Cannon, M., Holmans, P., Lewis, G., Linden, D.E., Jones, P.B., Davey Smith, G., O'Donovan, M.C., Owen, M.J., Walters, J.T., Zammit, S., 2016. Phenotypic Manifestation of Genetic Risk for Schizophrenia During Adolescence in the General Population. JAMA Psychiatry. 73 (3) 221-228.

Kay, S.R., Opler, L.A., Lindenmayer, J.P., 1988. Reliability and validity of the positive and negative syndrome scale for schizophrenics. Psychiatry Res. 23 (1) 99-110.

Kay, S.R., Opler, L.A., Lindenmayer, J.P., 1989. The Positive and Negative Syndrome Scale (PANSS): rationale and standardisation. Br. J. Psychiatry Suppl. (7) 59-67.

Ripke, S., O'Dushlaine, C., Chambert, K., Moran, J.L., Kahler, A.K., Akterin, S., et al., 2013. Genome-wide association analysis identifies 13 new risk loci for schizophrenia. Nat. Genet. 45 (10) $1150-1159$.

Schizophrenia Working Group of the Psychiatric Genomics Consortium, 2014. Biological insights from 108 schizophrenia-associated genetic loci. Nature 511 (7510) 421-427.

Sieradzka, D., Power, R.A., Freeman, D., Cardno, A.G., McGuire, P., Plomin, R., Meaburn, E.L. Dudbridge, F., Ronald, A., 2014. Are genetic risk factors for psychosis also associated with dimension-specific psychotic experiences in adolescence? PLoS. One. 9 (4) e94398.

Świtaj, P., Anczewska, M., Chrostek, A., Sabariego, C., Cieza, A., Bickenbach, J., Chatterji, S., 2012. Disability and schizophrenia: a systematic review of experienced psychosocial difficulties. BMC. Psychiatry, 12, 193.

Vassos, E., Di Forti, M., Coleman, J., Iyegbe, C., Prata, D., Euesden, J., O'Reilly, P., Curtis, C., Kolliakou, A., Patel, H., Newhouse, S., Traylor, M., Ajnakina, O., Mondelli, V., Marques, T.R., Gardner-Sood, P., Aitchison, K.J., Powell, J., Atakan, Z., Greenwood, K.E., Smith, S., Ismail, K., Pariante, C., Gaughran, F., Dazzan, P., Markus, H.S., David, A.S., Lewis, C.M., Murray, R.M., Breen, G., 2016. An examination of Polygenic Score Risk Prediction in Individuals with First Episode Psychosis. Biol. Psychiatry http://dx.doi.org/10.1016/j.biopsych.2016.06.028.

Zammit, S., Hamshere, M., Dwyer, S., Georgiva, L., Timpson, N., Moskvina, V. Richards, A., Evans, D.M., Lewis, G., Jones, P., Owen, M.J., O'Donovan, M.C., 2014. A population-based study of genetic variation and psychotic experiences in adolescents. Schizophr. Bull. 40 (6) 1254-1262. 
Table 1: Demographic/clinical characteristics comparing FEP subjects who participated in the genetic study versus those who did not

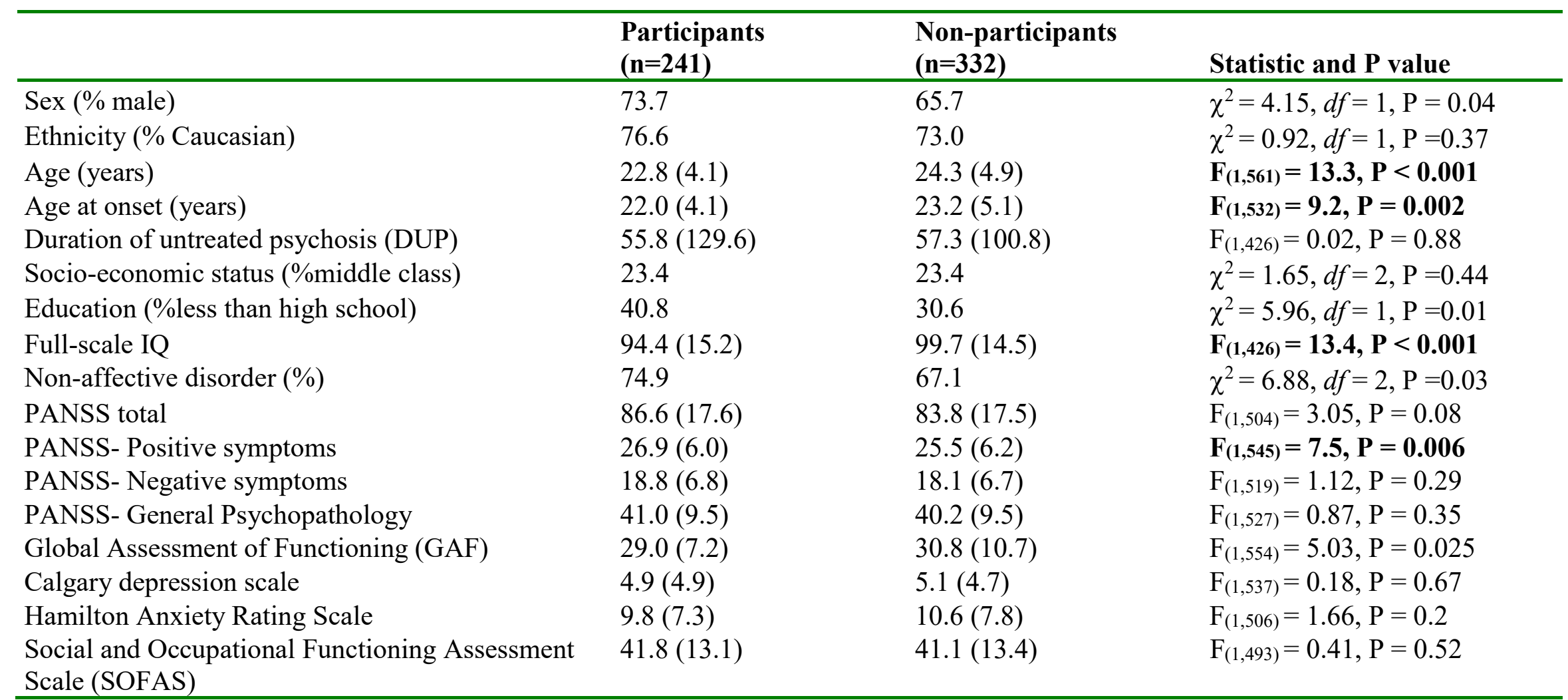

Values as mean (S.D.) unless otherwise specified; Results passing the threshold for statistical significance $(\mathrm{P}<0.01)$ have been highlighted 
Table 2a: Correlation analysis between PRS and clinical parameters at specified evaluation time points

\begin{tabular}{|c|c|c|c|c|c|c|c|c|c|c|}
\hline \multirow[t]{2}{*}{ Parameter } & \multicolumn{2}{|c|}{ Baseline } & \multicolumn{2}{|c|}{1 month } & \multicolumn{2}{|c|}{2 month } & \multicolumn{2}{|c|}{6 month } & \multicolumn{2}{|c|}{ 24month } \\
\hline & Coeff. & P-value & Coeff. & P-value & Coeff. & P-value & Coeff. & P-value & Coeff. & P-value \\
\hline PANSS total & 0.19 & 0.006 & 0.19 & 0.01 & 0.09 & 0.25 & 0.07 & 0.33 & -0.04 & 0.70 \\
\hline Positive symptoms & 0.08 & 0.260 & 0.12 & 0.10 & 0.07 & 0.35 & 0.06 & 0.38 & -0.13 & 0.10 \\
\hline Negative symptoms & 0.16 & 0.023 & 0.16 & 0.03 & 0.01 & 0.90 & 0.01 & 0.85 & 0.03 & 0.74 \\
\hline General Psychopathology & 0.20 & 0.003 & 0.16 & 0.03 & 0.14 & 0.07 & 0.10 & 0.15 & -0.03 & 0.72 \\
\hline Global Assessment of Functioning (GAF) & -0.02 & 0.801 & -0.02 & 0.76 & 0.07 & 0.32 & 0.07 & 0.36 & 0.09 & 0.26 \\
\hline Calgary depression scale & 0.06 & 0.390 & 0.01 & 0.92 & 0.04 & 0.56 & 0.05 & 0.48 & -0.21 & 0.01 \\
\hline Hamilton Anxiety Rating Scale & 0.24 & $<\mathbf{0 . 0 0 1}$ & 0.07 & 0.34 & 0.11 & 0.16 & 0.09 & 0.22 & -0.04 & 0.67 \\
\hline $\begin{array}{l}\text { Social and Occupational Functioning } \\
\text { Assessment Scale (SOFAS) }\end{array}$ & -0.09 & 0.225 & NA & NA & NA & NA & NA & NA & 0.10 & 0.28 \\
\hline
\end{tabular}


Table 2b: Scores for each clinical parameter given as mean (SD) at specified evaluation time points

\begin{tabular}{llcccc}
\hline Parameter & Baseline & 1 month & 2 month & 6 month & 24month \\
\hline & Mean (SD) & Mean (SD) & Mean (SD) & Mean (SD) & Mean (SD) \\
\hline PANSS total & $86.4(17.7)$ & $63.7(16.6)$ & $57.4(15.4)$ & $56.1(18.0)$ & $52.7(16.7)$ \\
Positive symptoms & $27.0(6.0)$ & $16.1(6.7)$ & $13.1(5.7)$ & $12.9(6.2)$ & $12.3(6.1)$ \\
Negative symptoms & $18.6(6.9)$ & $16.0(5.5)$ & $15.6(5.6)$ & $14.8(6.2)$ & $14.0(5.9)$ \\
General Psychopathology & $40.9(9.6)$ & $32.0(8.8)$ & $28.8(7.6)$ & $28.5(8.9)$ & $26.1(8.0)$ \\
Global Assessment of Functioning & $29.3(7.1)$ & $43.9(15.3)$ & $49.2(15.4)$ & $53.6(17.7)$ & $60.0(19.3)$ \\
(GAF) & $5.0(4.9)$ & $3.1(3.7)$ & $2.6(3.2)$ & $2.4(3.7)$ & $1.3(2.1)$ \\
Calgary depression scale & $9.7(7.1)$ & $5.5(4.8)$ & $4.6(5.1)$ & $4.1(4.9)$ & $3.1(4.2)$ \\
$\begin{array}{l}\text { Hamilton Anxiety Rating Scale } \\
\text { Social and Occupational Functioning }\end{array}$ & $42.1(13.0)$ & NA & NA & NA & $62.5(15.6)$ \\
Assessment Scale (SOFAS) & & & & &
\end{tabular}


Table 3: Demographic/clinical characteristics comparing Caucasian study participants with Caucasian FEP subjects who did not participate in the study

\begin{tabular}{|c|c|c|c|}
\hline & $\begin{array}{l}\text { Participants } \\
(n=162)\end{array}$ & $\begin{array}{l}\text { Non-participants } \\
(n=240)\end{array}$ & Statistic and $P$ value \\
\hline $\operatorname{Sex}(\%$ male $)$ & 75.9 & 67.5 & $\chi^{2}=3.33, d f=1, \mathrm{P}=0.07$ \\
\hline Age (years) & $23.0(4.0)$ & $24.5(4.6)$ & $F_{(1,398)}=-3.35, P=0.001$ \\
\hline Duration of untreated psychosis (DUP) & $58.6(141.1)$ & $56.4(94.4)$ & $\mathrm{F}_{(1,357)}=0.17, \mathrm{P}=0.86$ \\
\hline Socio-economic status (\%middle class) & 26.3 & 26.0 & $\chi^{2}=0.64, d f=2, \mathrm{P}=0.73$ \\
\hline Non-affective disorder $(\%)$ & 75.1 & 66.7 & $\chi^{2}=5.3, d f=2, \mathrm{P}=0.07$ \\
\hline PANSS total & $84.2(18.6)$ & $84.1(17.0)$ & $\mathrm{F}_{(1,363)}=0.03, \mathrm{P}=0.98$ \\
\hline PANSS- Positive symptoms & $26.4(6.2)$ & $26.0(6.1)$ & $\mathrm{F}_{(1,391)}=0.71, \mathrm{P}=0.48$ \\
\hline PANSS- Negative symptoms & $17.9(7.0)$ & $17.8(6.6)$ & $\mathrm{F}_{(1,375)}=0.14, \mathrm{P}=0.89$ \\
\hline PANSS- General Psychopathology & $39.9(9.9)$ & $40.3(9.4)$ & $\mathrm{F}_{(1,379)}=-0.39, \mathrm{P}=0.7$ \\
\hline
\end{tabular}

Values as mean (S.D.) unless otherwise specified 
Table 4: Correlation analysis between PRS and clinical parameters at specified evaluation time points in the Caucasian sample

\begin{tabular}{|c|c|c|c|c|c|c|c|c|c|c|}
\hline \multirow[t]{2}{*}{ Parameter } & \multicolumn{2}{|c|}{ Baseline } & \multicolumn{2}{|c|}{1 month } & \multicolumn{2}{|c|}{2 month } & \multicolumn{2}{|c|}{6 month } & \multicolumn{2}{|c|}{ 24month } \\
\hline & Coeff. & P-value & Coeff. & P-value & Coeff. & P-value & Coeff. & P-value & Coeff. & P-value \\
\hline PANSS total & 0.16 & 0.05 & 0.22 & 0.01 & 0.15 & 0.08 & 0.01 & 0.88 & -0.03 & 0.72 \\
\hline Positive symptoms & 0.005 & 0.95 & 0.13 & 0.14 & 0.11 & 0.22 & -0.04 & 0.63 & -0.10 & 0.27 \\
\hline Negative symptoms & 0.19 & 0.02 & 0.21 & 0.01 & 0.08 & 0.33 & 0.06 & 0.46 & 0.05 & 0.60 \\
\hline General Psychopathology & 0.19 & 0.02 & 0.18 & $\mathbf{0 . 0 3}$ & 0.20 & 0.02 & 0.06 & 0.51 & -0.03 & 0.70 \\
\hline Global Assessment of Functioning (GAF) & -0.02 & 0.80 & -0.09 & 0.32 & 0.06 & 0.49 & -0.05 & 0.57 & 0.02 & 0.80 \\
\hline Calgary depression scale & 0.12 & 0.13 & 0.02 & 0.79 & 0.09 & 0.29 & 0.04 & 0.62 & -0.26 & 0.01 \\
\hline Hamilton Anxiety Rating Scale & 0.22 & 0.01 & 0.09 & 0.28 & 0.17 & 0.05 & -0.06 & 0.47 & -0.04 & 0.71 \\
\hline $\begin{array}{l}\text { Social and Occupational Functioning } \\
\text { Assessment Scale (SOFAS) }\end{array}$ & -0.08 & 0.33 & NA & NA & NA & NA & NA & NA & 0.03 & 0.76 \\
\hline
\end{tabular}

Coeff.: Pearson Correlation Coefficient; NA: Not assessed; A less stringent threshold for significance $(\mathrm{P}<0.05)$ was applied to this post hoc analysis.

Results passing the threshold for statistical significance $(\mathrm{P}<0.05)$ have been highlighted. 


\section{Supplementary Table 1_Correlation matrix}

Correlations

\begin{tabular}{|c|c|c|c|c|c|c|c|c|c|c|c|c|c|c|c|c|c|c|c|c|c|}
\hline & & $\begin{array}{c}\text { pan } \\
\text { totl } \\
\text { b }\end{array}$ & $\begin{array}{c}\text { pan } \\
\text { ptot } \\
\text { b }\end{array}$ & $\begin{array}{c}\text { pan } \\
\text { ntot } \\
\text { b }\end{array}$ & $\begin{array}{c}\text { pan } \\
\text { gtot } \\
\text { b }\end{array}$ & $\begin{array}{c}\text { pan } \\
\text { totl } \\
1\end{array}$ & $\begin{array}{c}\text { pan } \\
\text { ptot } \\
1\end{array}$ & $\begin{array}{c}\text { pan } \\
\text { ntot } \\
1\end{array}$ & $\begin{array}{c}\text { pan } \\
\text { gtot } \\
1\end{array}$ & $\begin{array}{c}\text { pan } \\
\text { totl } \\
2\end{array}$ & $\begin{array}{c}\text { pan } \\
\text { ptot } \\
2\end{array}$ & $\begin{array}{c}\text { pan } \\
\text { ntot } \\
2 \\
\end{array}$ & $\begin{array}{c}\text { pan } \\
\text { gtot } \\
2 \\
\end{array}$ & $\begin{array}{c}\text { pan } \\
\text { totl } \\
6\end{array}$ & $\begin{array}{c}\text { pan } \\
\text { ptot } \\
6 \\
\end{array}$ & $\begin{array}{c}\text { pan } \\
\text { ntot } \\
6 \\
\end{array}$ & $\begin{array}{c}\text { pan } \\
\text { gtot } \\
6 \\
\end{array}$ & $\begin{array}{l}\text { pant } \\
\text { ot24 }\end{array}$ & $\begin{array}{c}\text { pan } \\
\text { pto2 } \\
4 \\
\end{array}$ & $\begin{array}{c}\text { pan } \\
\text { nto2 } \\
4 \\
\end{array}$ & $\begin{array}{c}\text { pan } \\
\text { gto2 } \\
4 \\
\end{array}$ \\
\hline $\begin{array}{l}\text { pant } \\
\text { otlb }\end{array}$ & $\begin{array}{l}\text { Pear } \\
\text { son } \\
\text { Corre } \\
\text { lation } \\
\text { Sig. } \\
\text { (2- } \\
\text { tailed } \\
\text { ) } \\
\mathrm{N}\end{array}$ & 209 & .596 & .782 & .917 & $\begin{array}{r}.00 \\
0 \\
177\end{array}$ & $\begin{array}{l}.001 \\
181\end{array}$ & .541 & 178 & $\begin{array}{r}.00 \\
0 \\
175\end{array}$ & 176 & .473 & .346 & $\begin{array}{r}.00 \\
4 \\
\\
173\end{array}$ & 178 & .285 & 175 & 155 & 162 & 159 & .165 \\
\hline $\begin{array}{l}\text { pan } \\
\text { ptot } \\
\text { b }\end{array}$ & $\begin{array}{l}\text { Pear } \\
\text { son } \\
\text { Corre } \\
\text { lation } \\
\text { Sig. } \\
\text { (2- } \\
\text { tailed } \\
\text { ) } \\
\mathrm{N}\end{array}$ & $\begin{array}{r}.59 \\
6^{* *} \\
\\
.00 \\
0 \\
209\end{array}$ & 218 & 211 & $\begin{array}{l}.000 \\
213\end{array}$ & $\begin{array}{r}.01 \\
1 \\
\\
182\end{array}$ & $\begin{array}{l}.001 \\
188\end{array}$ & $\begin{array}{l}.320 \\
183\end{array}$ & 184 & $\begin{array}{r}.04 \\
3 \\
\\
183\end{array}$ & 185 & $\begin{array}{l}.169 \\
184\end{array}$ & $\begin{array}{l}.065 \\
184\end{array}$ & $\begin{array}{r}.67 \\
3 \\
\\
181\end{array}$ & 187 & $.046^{-}$ & $\begin{array}{l}.380 \\
184\end{array}$ & $\begin{array}{r}.331 \\
161\end{array}$ & $\begin{array}{l}.246 \\
169\end{array}$ & $\begin{array}{l}.743 \\
165\end{array}$ & $\begin{array}{l}.220 \\
164\end{array}$ \\
\hline $\begin{array}{l}\text { pan } \\
\text { ntot } \\
\text { b }\end{array}$ & $\begin{array}{l}\text { Pear } \\
\text { son } \\
\text { Corre } \\
\text { lation } \\
\text { Sig. } \\
\text { (2- } \\
\text { tailed } \\
\text { ) } \\
\mathrm{N}\end{array}$ & $\begin{array}{r}.78 \\
2^{* *} \\
\\
.00 \\
0 \\
209\end{array}$ & $\begin{array}{l}.038 \\
211\end{array}$ & 212 & $\begin{array}{l}.000 \\
210\end{array}$ & $\begin{array}{r}.00 \\
0\end{array}$ & $\begin{array}{l}.184 \\
183\end{array}$ & 179 & 179 & $\begin{array}{r}.00 \\
0\end{array}$ & .771 & $\begin{array}{l}.000 \\
179\end{array}$ & 178 & $\begin{array}{r}.00 \\
0 \\
176\end{array}$ & .225 & .000 & $\begin{array}{l}.001 \\
178\end{array}$ & $\begin{array}{l}.012 \\
156\end{array}$ & $.043^{-}$ & 160 & $\begin{array}{l}.079 \\
159\end{array}$ \\
\hline $\begin{array}{l}\text { pan } \\
\text { gtot } \\
\text { b }\end{array}$ & $\begin{array}{l}\text { Pear } \\
\text { son } \\
\text { Corre } \\
\text { lation } \\
\text { Sig. } \\
(2- \\
\text { tailed } \\
\text { ) }\end{array}$ & $\begin{array}{r}.91 \\
7^{* *} \\
.00 \\
0\end{array}$ & .391 & .000 & 1 & $\begin{array}{l}.54 \\
2^{* *}\end{array}$ & $.278_{\star \star}$ & .444 & $.543_{* \star}$ & $\begin{array}{l}.38 \\
9^{* *}\end{array}$ & .157 * & .380 & .417 & $\begin{array}{r}.16 \\
4^{*}\end{array}$ & .275 & .197 & .015 & .080 & .041 & .012 & .163 \\
\hline
\end{tabular}




\begin{tabular}{|c|c|c|c|c|c|c|c|c|c|c|c|c|c|c|c|c|c|c|c|c|c|}
\hline & $\mathrm{N}$ & 209 & 213 & 210 & 214 & 181 & 185 & 182 & 182 & 179 & 181 & 180 & 180 & 177 & 183 & 179 & 180 & 159 & 166 & 163 & 161 \\
\hline $\begin{array}{l}\text { pant } \\
\text { otl1 }\end{array}$ & $\begin{array}{l}\text { Pear } \\
\text { son } \\
\text { Corre } \\
\text { lation } \\
\text { Sig. } \\
(2- \\
\text { tailed } \\
)^{N} \\
\mathrm{~N}\end{array}$ & $\begin{array}{r}.51 \\
7^{\star *} \\
\\
.00 \\
0 \\
\\
177\end{array}$ & $\begin{array}{l}.011 \\
182\end{array}$ & $\begin{array}{l}.000 \\
178\end{array}$ & $\begin{array}{l}.000 \\
181\end{array}$ & 183 & .770 & $\begin{array}{l}.000 \\
183\end{array}$ & $\begin{array}{l}.000 \\
183\end{array}$ & $\begin{array}{r}.00 \\
0 \\
163\end{array}$ & .568 & $\begin{array}{l}.000 \\
164\end{array}$ & $\begin{array}{l}.000 \\
164\end{array}$ & $\begin{array}{r}.00 \\
0 \\
\\
154\end{array}$ & $\begin{array}{l}.000 \\
160\end{array}$ & .387 & $\begin{array}{l}.000 \\
157\end{array}$ & $\begin{array}{l}.000 \\
138\end{array}$ & $\begin{array}{l}.436 \\
143\end{array}$ & $\begin{array}{l}.000 \\
141\end{array}$ & $\begin{array}{l}.276 \\
* * \\
.001 \\
139\end{array}$ \\
\hline $\begin{array}{l}\text { pan } \\
\text { ptot } \\
1\end{array}$ & $\begin{array}{l}\text { Pear } \\
\text { son } \\
\text { Corre } \\
\text { lation } \\
\text { Sig. } \\
(2- \\
\text { tailed } \\
)_{\mathrm{N}}\end{array}$ & $\begin{array}{r}.24 \\
0^{\star *} \\
\\
.00 \\
1 \\
\\
181\end{array}$ & .230 & $\begin{array}{r}.184 \\
183\end{array}$ & .278 & $\begin{array}{r}.00 \\
0 \\
\\
183\end{array}$ & 189 & $\begin{array}{l}.041 \\
184\end{array}$ & .643 & $\begin{array}{r}.00 \\
0 \\
\\
168\end{array}$ & 170 & $\begin{array}{l}.011 \\
169\end{array}$ & .551 & $\begin{array}{r}.00 \\
0 \\
159\end{array}$ & 165 & 161 & 162 & $\begin{array}{l}.007 \\
142\end{array}$ & 148 & $\begin{array}{l}.022 \\
145\end{array}$ & $\begin{array}{r}.030 \\
144\end{array}$ \\
\hline $\begin{array}{l}\text { pan } \\
\text { ntot } \\
1\end{array}$ & $\begin{array}{l}\text { Pear } \\
\text { son } \\
\text { Corre } \\
\text { lation } \\
\text { Sig. } \\
(2- \\
\text { tailed } \\
)_{\mathrm{N}}\end{array}$ & $\begin{array}{r}.54 \\
1^{* *} \\
\\
.00 \\
0 \\
178\end{array}$ & $\begin{array}{r}.320 \\
183\end{array}$ & $\begin{array}{l}.000 \\
179\end{array}$ & $\begin{array}{l}.000 \\
182\end{array}$ & $\begin{array}{r}.00 \\
0 \\
\\
183\end{array}$ & $\begin{array}{l}.041 \\
184\end{array}$ & 184 & $\begin{array}{l}.000 \\
183\end{array}$ & $\begin{array}{r}.00 \\
0 \\
164\end{array}$ & $\begin{array}{l}.296 \\
166\end{array}$ & $\begin{array}{l}.000 \\
165\end{array}$ & $\begin{array}{l}.000 \\
165\end{array}$ & $\begin{array}{r}.00 \\
0 \\
\\
155\end{array}$ & $\begin{array}{l}.329 \\
161\end{array}$ & $\begin{array}{l}.000 \\
157\end{array}$ & $\begin{array}{l}.002 \\
158\end{array}$ & $\begin{array}{l}.051 \\
139\end{array}$ & $\begin{array}{r}.146 \\
144\end{array}$ & $\begin{array}{l}.000 \\
142\end{array}$ & $\begin{array}{r}.153 \\
140\end{array}$ \\
\hline $\begin{array}{l}\text { pan } \\
\text { gtot } \\
1\end{array}$ & $\begin{array}{l}\text { Pear } \\
\text { son } \\
\text { Corre } \\
\text { lation } \\
\text { Sig. } \\
(2- \\
\text { tailed } \\
)_{\mathrm{N}}\end{array}$ & $\begin{array}{r}.45 \\
8^{* *} \\
\\
.00 \\
0 \\
178\end{array}$ & $\begin{array}{l}.023 \\
184\end{array}$ & $\begin{array}{l}.000 \\
179\end{array}$ & $\begin{array}{l}.000 \\
182\end{array}$ & $\begin{array}{r}.00 \\
0 \\
183\end{array}$ & $\begin{array}{l}.000 \\
185\end{array}$ & $\begin{array}{l}.000 \\
183\end{array}$ & 185 & $\begin{array}{r}.00 \\
0 \\
\\
165\end{array}$ & $\begin{array}{l}.000 \\
167\end{array}$ & $\begin{array}{l}.000 \\
166\end{array}$ & $\begin{array}{l}.000 \\
166\end{array}$ & $\begin{array}{r}.00 \\
0 \\
\\
155\end{array}$ & $\begin{array}{l}.000 \\
161\end{array}$ & .290 & $\begin{array}{l}.000 \\
158\end{array}$ & $\begin{array}{l}.001 \\
139\end{array}$ & $\begin{array}{l}.437 \\
144\end{array}$ & $\begin{array}{l}.001 \\
142\end{array}$ & $\begin{array}{l}.001 \\
140\end{array}$ \\
\hline $\begin{array}{l}\text { pant } \\
\text { otl2 }\end{array}$ & $\begin{array}{l}\text { Pear } \\
\text { son } \\
\text { Corre } \\
\text { lation }\end{array}$ & $\begin{array}{l}.38 \\
5^{* *}\end{array}$ & .150 & .360 & .389 & $\begin{array}{l}.77 \\
3^{* *}\end{array}$ & .606 & .497 & .714 & 1 & $.786_{*}$ & .704 & .931 & $\begin{array}{c}.46 \\
6^{* *}\end{array}$ & .445 & .298 & .448 & .462 & .179 & .447 & .471 \\
\hline
\end{tabular}




\begin{tabular}{|c|c|c|c|c|c|c|c|c|c|c|c|c|c|c|c|c|c|c|c|c|c|}
\hline & $\begin{array}{l}\text { Sig. } \\
(2- \\
\text { tailed } \\
{ }_{\mathrm{N}}\end{array}$ & $\begin{array}{r}.00 \\
0 \\
175\end{array}$ & $\begin{array}{l}.043 \\
183\end{array}$ & $\begin{array}{l}.000 \\
178\end{array}$ & 179 & $\begin{array}{r}.00 \\
0 \\
163\end{array}$ & 168 & 164 & 165 & 184 & .000 & 184 & 184 & $\begin{array}{r}.00 \\
0 \\
159\end{array}$ & 164 & 161 & .000 & 136 & .033 & 139 & .000 \\
\hline $\begin{array}{l}\text { pan } \\
\text { ptot } \\
2\end{array}$ & $\begin{array}{l}\text { Pear } \\
\text { son } \\
\text { Corre } \\
\text { lation } \\
\text { Sig. } \\
(2- \\
\text { tailed } \\
\text { ) } \\
\text { N }\end{array}$ & $\begin{array}{r}.11 \\
2 \\
\\
.13 \\
7 \\
\\
176\end{array}$ & $\begin{array}{l}.020 \\
185\end{array}$ & $\begin{array}{l}.771 \\
179\end{array}$ & $\begin{array}{l}.035 \\
181\end{array}$ & $\begin{array}{r}.00 \\
0 \\
\\
165\end{array}$ & $\begin{array}{l}.000 \\
170\end{array}$ & $\begin{array}{l}.296 \\
166\end{array}$ & $\begin{array}{l}.000 \\
167\end{array}$ & $\begin{array}{r}.00 \\
0 \\
\\
184\end{array}$ & 186 & $\begin{array}{l}.001 \\
185\end{array}$ & $\begin{array}{l}.000 \\
185\end{array}$ & $\begin{array}{r}.00 \\
0 \\
160\end{array}$ & $\begin{array}{l}.000 \\
166\end{array}$ & $\begin{array}{l}.285 \\
162\end{array}$ & $\begin{array}{l}.000 \\
163\end{array}$ & $\begin{array}{l}.000 \\
138\end{array}$ & $\begin{array}{l}.005 \\
144\end{array}$ & $\begin{array}{l}.000 \\
141\end{array}$ & $\begin{array}{l}.000 \\
140\end{array}$ \\
\hline $\begin{array}{l}\text { pan } \\
\text { ntot } \\
2\end{array}$ & $\begin{array}{l}\text { Pear } \\
\text { son } \\
\text { Corre } \\
\text { lation } \\
\text { Sig. } \\
\text { (2- } \\
\text { tailed } \\
\text { ) } \\
\text { N }\end{array}$ & $\begin{array}{r}.00 \\
0 \\
176\end{array}$ & $\begin{array}{l}.169 \\
184\end{array}$ & $\begin{array}{l}.000 \\
179\end{array}$ & $\begin{array}{l}.000 \\
180\end{array}$ & $\begin{array}{r}.00 \\
0 \\
164\end{array}$ & $\begin{array}{l}.011 \\
169\end{array}$ & $\begin{array}{l}.000 \\
165\end{array}$ & $\begin{array}{l}.000 \\
166\end{array}$ & $\begin{array}{r}.00 \\
0\end{array}$ & $\begin{array}{r}.001 \\
185\end{array}$ & 185 & $\begin{array}{l}.000 \\
184\end{array}$ & $\begin{array}{r}.00 \\
0 \\
160\end{array}$ & $\begin{array}{l}.017 \\
165\end{array}$ & $\begin{array}{l}.000 \\
162\end{array}$ & $\begin{array}{l}.001 \\
162\end{array}$ & $\begin{array}{l}.001 \\
137\end{array}$ & $\begin{array}{c}.873 \\
143\end{array}$ & $\begin{array}{l}.000 \\
140\end{array}$ & $.272_{* *}$ \\
\hline $\begin{array}{l}\text { pan } \\
\text { gtot } \\
2\end{array}$ & $\begin{array}{l}\text { Pear } \\
\text { son } \\
\text { Corre } \\
\text { lation } \\
\text { Sig. } \\
\text { (2- } \\
\text { tailed } \\
\text { ) } \\
\text { N }\end{array}$ & $\begin{array}{r}.00 \\
0 \\
175\end{array}$ & $\begin{array}{l}.065 \\
184\end{array}$ & $\begin{array}{l}.001 \\
178\end{array}$ & $\begin{array}{l}.000 \\
180\end{array}$ & $\begin{array}{r}.00 \\
0 \\
164\end{array}$ & $\begin{array}{l}.000 \\
169\end{array}$ & $\begin{array}{l}.000 \\
165\end{array}$ & $\begin{array}{l}.000 \\
166\end{array}$ & $\begin{array}{r}.00 \\
0 \\
\\
184\end{array}$ & $\begin{array}{l}.000 \\
185\end{array}$ & $\begin{array}{l}.000 \\
184\end{array}$ & 185 & $\begin{array}{r}.00 \\
0 \\
159\end{array}$ & $\begin{array}{l}.000 \\
165\end{array}$ & $\begin{array}{l}.010 \\
161\end{array}$ & $\begin{array}{l}.000 \\
162\end{array}$ & .417 & $\begin{array}{l}.044 \\
143\end{array}$ & $.333_{* *}$ & $\begin{array}{r}.000 \\
139\end{array}$ \\
\hline $\begin{array}{l}\text { pant } \\
\text { otl6 }\end{array}$ & $\begin{array}{l}\text { Pear } \\
\text { son } \\
\text { Corre } \\
\text { lation } \\
\text { Sig. } \\
\text { (2- } \\
\text { tailed } \\
\text { ) } \\
\text { N }\end{array}$ & $\begin{array}{r}.00 \\
4 \\
\\
173\end{array}$ & $\begin{array}{l}.673 \\
181\end{array}$ & $\begin{array}{l}.000 \\
176\end{array}$ & $\begin{array}{l}.029 \\
177\end{array}$ & $\begin{array}{r}.00 \\
0\end{array}$ & .000 & .000 & .000 & $\begin{array}{r}.00 \\
0\end{array}$ & .000 & $.348_{* *}$ & $.411_{\star \star}$ & 182 & .000 & .000 & .000 & .000 & .088 & .404 & .000 \\
\hline
\end{tabular}




\begin{tabular}{|c|c|c|c|c|c|c|c|c|c|c|c|c|c|c|c|c|c|c|c|c|c|}
\hline $\begin{array}{l}\text { pan } \\
\text { ptot } \\
6\end{array}$ & $\begin{array}{l}\text { Pear } \\
\text { son } \\
\text { Corre } \\
\text { lation } \\
\text { Sig. } \\
\text { (2- } \\
\text { tailed } \\
\text { ) } \\
\mathrm{N}\end{array}$ & $\begin{array}{r}.28 \\
4 \\
\\
178\end{array}$ & $\begin{array}{l}.072 \\
187\end{array}$ & $\begin{array}{l}.225 \\
181\end{array}$ & $\begin{array}{l}.275 \\
183\end{array}$ & $\begin{array}{r}.00 \\
0 \\
160\end{array}$ & 165 & 161 & .341 & $\begin{array}{r}.00 \\
0 \\
164\end{array}$ & .531 & 165 & .407 & $\begin{array}{r}.00 \\
0 \\
182\end{array}$ & 188 & 184 & .708 & 143 & 150 & 147 & .302 \\
\hline $\begin{array}{l}\text { pan } \\
\text { ntot } \\
6\end{array}$ & $\begin{array}{l}\text { Pear } \\
\text { son } \\
\text { Corre } \\
\text { lation } \\
\text { Sig. } \\
\text { (2- } \\
\text { tailed } \\
)_{\mathrm{N}}\end{array}$ & $\begin{array}{r}.00 \\
0 \\
175\end{array}$ & $\begin{array}{r}.535 \\
183\end{array}$ & $\begin{array}{l}.000 \\
178\end{array}$ & $\begin{array}{l}.008 \\
179\end{array}$ & $\begin{array}{r}.00 \\
0 \\
156\end{array}$ & $\begin{array}{r}.348 \\
161\end{array}$ & $\begin{array}{l}.000 \\
157\end{array}$ & $\begin{array}{l}.000 \\
157\end{array}$ & $\begin{array}{r}.00 \\
0 \\
161\end{array}$ & $\begin{array}{r}.285 \\
162\end{array}$ & $\begin{array}{l}.000 \\
162\end{array}$ & $\begin{array}{l}.010 \\
161\end{array}$ & $\begin{array}{r}.00 \\
0 \\
182\end{array}$ & 184 & 184 & 182 & $\begin{array}{l}.000 \\
140\end{array}$ & $\begin{array}{l}.617 \\
147\end{array}$ & 144 & .251 \\
\hline $\begin{array}{l}\text { pan } \\
\text { gtot } \\
6\end{array}$ & $\begin{array}{l}\text { Pear } \\
\text { son } \\
\text { Corre } \\
\text { lation } \\
\text { Sig. } \\
(2- \\
\text { tailed } \\
)_{\mathrm{N}}\end{array}$ & $\begin{array}{r}.01 \\
3 \\
175\end{array}$ & $\begin{array}{r}.380 \\
184\end{array}$ & $\begin{array}{l}.001 \\
178\end{array}$ & $\begin{array}{l}.015 \\
180\end{array}$ & $\begin{array}{r}.00 \\
0 \\
157\end{array}$ & 162 & .002 & 158 & $\begin{array}{r}.00 \\
0 \\
161\end{array}$ & 163 & 162 & 162 & $\begin{array}{r}.00 \\
0\end{array}$ & 185 & 182 & 185 & 140 & 147 & 144 & .388 \\
\hline $\begin{array}{l}\text { pant } \\
\text { ot24 }\end{array}$ & $\begin{array}{l}\text { Pear } \\
\text { son } \\
\text { Corre } \\
\text { lation } \\
\text { Sig. } \\
(2- \\
\text { tailed } \\
)^{\mathrm{N}}\end{array}$ & $\begin{array}{r}.03 \\
3 \\
155\end{array}$ & $\begin{array}{r}.331 \\
161\end{array}$ & $\begin{array}{l}.012 \\
156\end{array}$ & $\begin{array}{l}.080 \\
159\end{array}$ & $\begin{array}{r}.00 \\
0 \\
138\end{array}$ & $\begin{array}{l}.007 \\
142\end{array}$ & $\begin{array}{l}.051 \\
139\end{array}$ & $\begin{array}{l}.001 \\
139\end{array}$ & $\begin{array}{r}.00 \\
0 \\
136\end{array}$ & $\begin{array}{l}.000 \\
138\end{array}$ & $\begin{array}{l}.001 \\
137\end{array}$ & $\begin{array}{l}.000 \\
137\end{array}$ & $\begin{array}{r}.00 \\
0 \\
138\end{array}$ & 143 & $\begin{array}{l}.000 \\
140\end{array}$ & 140 & 162 & $\begin{array}{l}.000 \\
162\end{array}$ & $\begin{array}{l}.000 \\
162\end{array}$ & $\begin{array}{l}.000 \\
162\end{array}$ \\
\hline $\begin{array}{l}\text { pan } \\
\text { pto2 } \\
4\end{array}$ & $\begin{array}{l}\text { Pear } \\
\text { son } \\
\text { Corre } \\
\text { lation } \\
\text { Sig. } \\
\text { (2- }\end{array}$ & $\begin{array}{r}- \\
.01 \\
3 \\
.87 \\
2\end{array}$ & 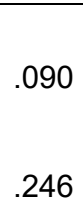 & $\begin{array}{r}- \\
.043 \\
.582\end{array}$ & $\begin{array}{r}- \\
.041 \\
.598\end{array}$ & $\begin{array}{r}.06 \\
6 \\
.43 \\
6\end{array}$ & .059 & $.122^{-}$ & 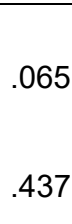 & $\begin{array}{r}.17 \\
9^{*} \\
\\
.03 \\
3\end{array}$ & .233 & .013 & 169 & $\begin{array}{r}.14 \\
2 \\
\\
.08 \\
8\end{array}$ & .013 & .042 & .119 & .785 & 1 & .000 & .629 \\
\hline
\end{tabular}




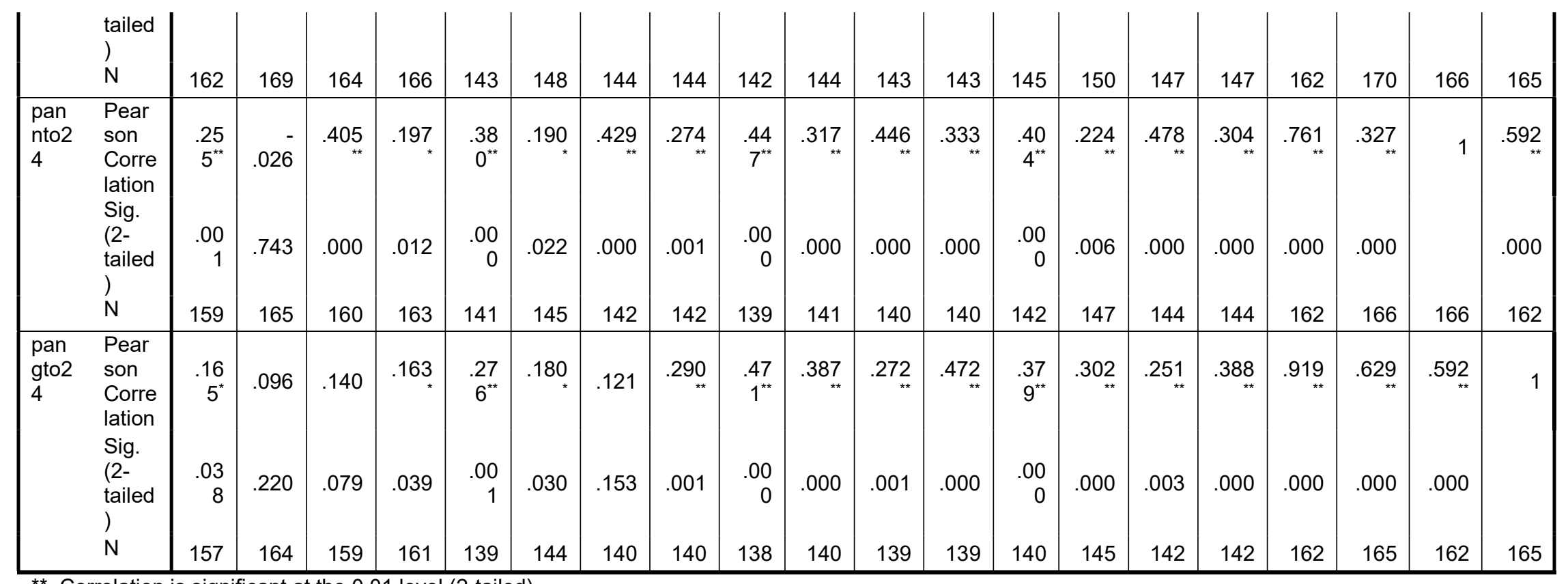

${ }^{* *}$. Correlation is significant at the 0.01 level (2-tailed).

*. Correlation is significant at the 0.05 level (2-tailed).

\section{Variables}

pantotlb PANSS total score at baseline

panptotb PANSS total positive symptom sub-scale score at baseline

panntotb PANSS total negative symptom sub-scale score at baseline

pangtotb PANSS total general psychopathology sub-scale score at baseline

pantotl1 PANSS total score at 1 month

panptot1 PANSS total positive symptom sub-scale score at 1 month

panntot1 PANSS total negative symptom sub-scale score at 1 month

pangtot1 PANSS total general psychopathology sub-scale score at 1 month

pantotl2 PANSS total score at 2 month

panptot2 PANSS total positive symptom sub-scale score at 2 month

panntot2 PANSS total negative symptom sub-scale score at 2 month 


\section{Supplementary Table 1_Details on SNP selection}

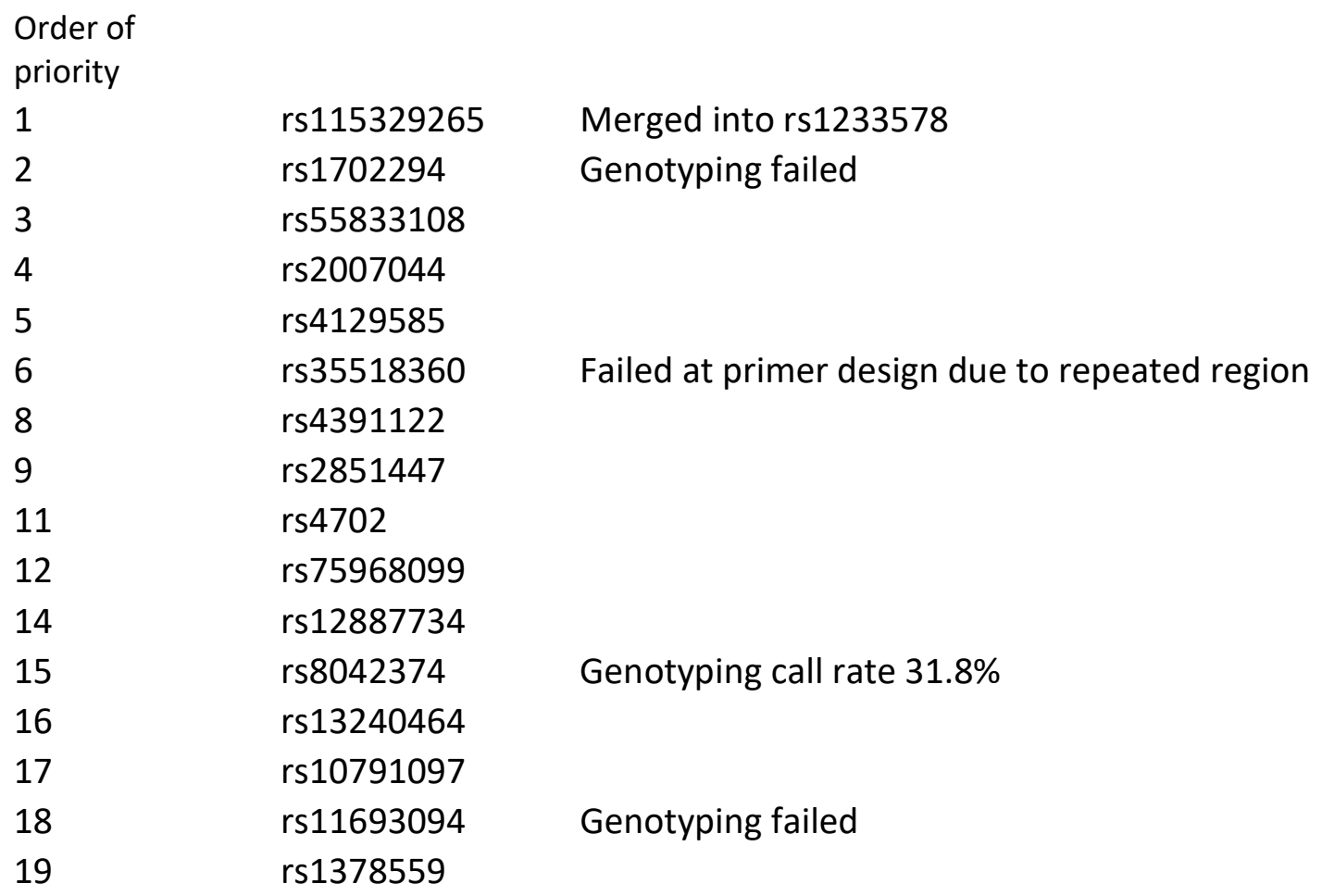




\begin{tabular}{|c|c|c|}
\hline 20 & rs7893279 & \\
\hline 21 & rs12826178 & \\
\hline 22 & rs12129573 & \\
\hline 23 & rs6704768 & \\
\hline 24 & rs55661361 & \\
\hline 25 & rs9636107 & \\
\hline 29 & rs6065094 & \\
\hline 30 & rs11682175 & \\
\hline 31 & rs950169 & \\
\hline 32 & rs72934570 & \\
\hline 33 & rs6434928 & \\
\hline 34 & rs9607782 & \\
\hline 35 & rs36068923 & \\
\hline 36 & rs17194490 & \\
\hline 37 & rs2514218 & \\
\hline 38 & rs75059851 & Genotyping call rate $72.03 \%$ \\
\hline 39 & rs2535627 & \\
\hline 40 & rs12691307 & \\
\hline 42 & rs7432375 & \\
\hline 46 & rs5937157 & Failed at primer design due to neighbor SNPs \\
\hline 47 & rs4523957 & \\
\hline 48 & rs12704290 & Failed at primer design due to repeated region \\
\hline 49 & rs12903146 & \\
\hline 50 & rs11210892 & \\
\hline 51 & rs2905426 & \\
\hline 52 & rs140505938 & Failed at primer design due to repeated region \\
\hline 54 & rs4648845 & \\
\hline \multirow[t]{2}{*}{55} & rs7405404 & \\
\hline & No unique SNP & \\
\hline 57 & ID & \\
\hline
\end{tabular}




\begin{tabular}{|c|c|c|}
\hline 56 & rs6466055 & \\
\hline 58 & rs4766428 & \\
\hline 59 & rs10520163 & \\
\hline 60 & rs117074560 & \\
\hline 61 & rs6002655 & Genotyping failed \\
\hline 63 & rs9420 & \\
\hline 64 & rs11027857 & \\
\hline 65 & rs1498232 & \\
\hline 66 & rs3735025 & \\
\hline 67 & rs11139497 & Genotyping failed \\
\hline 68 & rs77149735 & \\
\hline 69 & rs56205728 & \\
\hline 70 & rs2053079 & \\
\hline 71 & rs16867576 & \\
\hline 72 & rs4330281 & \\
\hline 73 & rs3849046 & \\
\hline 74 & rs2693698 & \\
\hline 75 & rs2332700 & \\
\hline 76 & rs1501357 & \\
\hline 77 & rs6984242 & \\
\hline 79 & rs79212538 & \\
\hline 80 & rs3768644 & \\
\hline 81 & rs77502336 & \\
\hline 82 & rs6704641 & \\
\hline 83 & rs59979824 & \\
\hline 84 & rs1106568 & \\
\hline 85 & rs10503253 & \\
\hline 87 & rs11685299 & \\
\hline 88 & rs7819570 & Failed at primer design due to repeated region \\
\hline
\end{tabular}




\begin{tabular}{|c|c|c|}
\hline 90 & rs9922678 & \\
\hline 92 & rs2068012 & \\
\hline 93 & rs832187 & \\
\hline 94 & rs8044995 & \\
\hline 96 & rs8082590 & \\
\hline 97 & rs12148337 & \\
\hline 98 & rs12325245 & \\
\hline 102 & rs73229090 & \\
\hline 104 & rs12845396 & Failed at primer design due to repeated region \\
\hline 106 & rs9841616 & \\
\hline 108 & rs1339227 & \\
\hline 110 & rs4388249 & \\
\hline 111 & rs215411 & \\
\hline 112 & rs11740474 & \\
\hline 114 & rs12421382 & \\
\hline 115 & rs211829 & \\
\hline 116 & rs679087 & Genotyping call rate $42 \%$ \\
\hline 118 & rs7801375 & \\
\hline 120 & rs6670165 & \\
\hline 121 & rs7523273 & \\
\hline 122 & rs7267348 & \\
\hline 123 & rs4240748 & \\
\hline 124 & rs2909457 & \\
\hline 125 & rs56873913 & Failed at primer design due to repeated region \\
\hline 127 & rs10860964 & \\
\hline Failed & rs10803138 & \\
\hline Failed & rs111294930 & \\
\hline Failed & rs2973155 & \\
\hline Failed & rs7907645 & \\
\hline
\end{tabular}




$\begin{array}{ll}\text { Failed } & \text { rs11191419 } \\ \text { exclude } & \text { rs76869799 } \\ \text { exclude } & \text { rs14403 } \\ \text { exclude } & \text { rs75575209 } \\ \text { exclude } & \text { rs10043984 } \\ \text { exclude } & \text { rs12522290 } \\ \text { exclude } & \text { rs2239063 } \\ \text { exclude } & \text { rs324017 } \\ \text { exclude } & \text { rs190065944 } \\ \text { exclude } & \text { rs78322266 } \\ \text { exclude } & \text { rs715170 } \\ \text { exclude } & \text { rs1023500 }\end{array}$

